\title{
Blood serum acute phase proteins and iron dynamics during acute phase response of Salmonella enterica serotype Dublin experimentally infected buffalo calves
}

\author{
André M. Santana ${ }^{\mathrm{a}, *}$, Daniela G. Silva ${ }^{\mathrm{a}}$, Funmilola C. Thomas ${ }^{\mathrm{b}}$, Priscila A. Bernardes ${ }^{\mathrm{a}}$, \\ Lucas J.L. Pizauro ${ }^{a}$, Clarissa H. Santana ${ }^{a}$, Richard J.S. Burchmore ${ }^{c}$, Peter D. Eckersall ${ }^{d}$, \\ José J. Fagliari ${ }^{\mathrm{a}}$ \\ a Department of Veterinary Clinic and Surgery, School of Agricultural and Veterinary Sciences, São Paulo State University (FCAV/UNESP), Jaboticabal, SP, Brazil \\ b Department of Veterinary Physiology and Pharmacology, College of Veterinary Medicine, Federal University of Agriculture, Abeokuta, Nigeria \\ ${ }^{\mathrm{c}}$ Institute of Infection, Immunity and Inflammation, Glasgow Polyomics Facility, College of Medical, Veterinary and Life Sciences, University of Glasgow, Glasgow, United \\ Kingdom \\ ${ }^{\mathrm{d}}$ Institute of Biodiversity, Animal Health and Comparative Medicine, College of Medical, Veterinary and Life Sciences, University of Glasgow, Glasgow, United Kingdom
}

\section{A R T I C L E I N F O}

\section{Keywords:}

Ceruloplasmin

Electrophoresis

Fibrinogen

Haptoglobin

Transferrin

Water buffalo

\begin{abstract}
A B S T R A C T
The study aimed to evaluate clinical signs, blood serum acute phase proteins (APP) and iron dynamics during the acute phase response (APR) of Salmonella Dublin experimentally infected Murrah buffalo calves. Six buffalo calves constituted the control group (CNT) and six were orally inoculate with $10^{8} \mathrm{CFU}$ of $S$. Dublin (INF). Clinical evaluation was performed, rectal swabs to detect $S$. Dublin strains were collected and venous blood was sampled before and throughout seven days after inoculation. The APP fractions $\beta$-haptoglobin, $\alpha$-haptoglobin, ceruloplasmin and transferrin were analyzed by 1-D and 2-D electrophoresis. Proteins were identified using LC/ESIMS/MS and NCBI database. Plasma fibrinogen, serum iron and serum haptoglobin concentrations were measured. The inoculation of $10^{8} \mathrm{CFU}$ of $S$. Dublin was effective in inducing clinical signs of Salmonellosis, such as hyperthermia and diarrhea. 1-DE showed that $\beta$ and $\alpha$-haptoglobin increased $204 \%(\mathrm{p}=0.008)$ and $184 \%$ $(\mathrm{p}=0.022) 48 \mathrm{~h}$ after inoculation (HAI), respectively, with highest concentrations $120 \mathrm{HAI}$ (498\% increased, $\mathrm{p}=0.012 ; 431 \%$ increased, $\mathrm{p}=0.011)$ and $168 \mathrm{HAI}(492 \%$ increased, $\mathrm{p}=0.019 ; 523 \%$ increased, $\mathrm{p}=0.028)$. 2 -DE showed that the expression of two spots, identified as $\beta$-haptoglobin, were increased $693 \%(\mathrm{p}=0.0006)$ and $580 \%(\mathrm{p}=0.0003) 168 \mathrm{HAI}$, respectively, while one spot, identified as $\alpha$-haptoglobin, increased $714 \%$ $(\mathrm{p}=0.040)$. Haptoglobin concentrations increased 1339\% ( $\mathrm{p}<0.0001) 168$ HAI. 1-DE showed that ceruloplasmin increased $42 \%(\mathrm{p}=0.034) 48 \mathrm{HAI}$, with highest concentration 120 HAI (133\% increased, $\mathrm{p}=0.022)$. 2-DE showed that the expression of two spots, identified as ceruloplasmin, were increased $218 \%$ $(\mathrm{p}=0.0153)$ and $85 \%(\mathrm{p}=0.0143) 168 \mathrm{HAI}$, respectively. Fibrinogen increased $78 \%(\mathrm{p}=0.012) 96 \mathrm{HAI}$, with highest concentration 120 HAI (increased 114\%, $p=0.002$ ). Iron decreased 33\% 24 HAI ( $p=0.015)$ and 37\% 72 HAI ( $p=0.029$ ), and began to be restored 96 HAI. 1-DE showed that transferrin decreased $23 \% 120$ HAI $(\mathrm{p}=0.047)$, and that values were restored 168 HAI. 2-DE showed that expression patterns of transferrin comparing $0 \mathrm{~h}$ and $168 \mathrm{HAI}$ were similar, evidencing that values were restored $168 \mathrm{HAI}$. In conclusion, the inoculation of $10^{8} \mathrm{CFU}$ was effective in inducing hyperthermia and diahrrea. $\beta$ and $\alpha$-haptoglobin, ceruloplasmin and fibrinogen worked as positive APP during the APR to $S$. Dublin infection and are potential biomarker candidates. Concentrations of iron and transferrin decreased during the infection, highlighting the fact that mechanisms for restricting iron availability are part of the APR triggered against $S$. Dublin infection in buffalo calves.
\end{abstract}

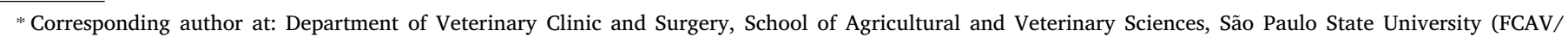
UNESP), Via de Acesso Prof. Paulo Donato Castellane s/n, 14884-900, Jaboticabal, SP, Brazil.

E-mail address: andrevetms@gmail.com (A.M. Santana). 


\section{Introduction}

With origin in the Asian continent, nowadays buffaloes can be found, practically, on all continents, with a world population of 194 million animals spread across 45 countries (FAO, 2017). South America has 1.3 million animals, most of which are located in Brazil (FAO, 2017), where the buffalo is considered a viable alternative for milk and meat production. According to the Ministry of Agriculture, Livestock and Food Supply (MAPA, 2017), the Brazilian buffalo population is mostly in the North $(50.8 \%)$ and Northeast $(28.4 \%)$ regions, followed by the Southeast $(10.2 \%)$. While the North/Northeast regions concentrates the largest number of animals, specialized in meat production, it is in the southeast region where the largest production of buffalo milk and derivatives reside (Bernardes, 2006).

Reports show that diarrhea caused by Salmonella can account for $13-14 \%$ of all cases in buffalo calves, with a mortality rate ranging from 40 to $72 \%$ (Fagiolo et al., 2005). In this sense, Salmonellosis in buffalo calves is a widespread disease characterized by severe gastrointestinal lesions, profuse diarrhea, and severe dehydration, occasionally exhibiting a systemic course (Borriello et al., 2012). Therefore, Salmonellosis, as many other diseases, causes inflammation and is liable to trigger an acute phase response (APR) in buffalo as has been described in cattle (Villarreal-Ramos et al., 2000).

As part of the acute phase response (APR), triggered by inflammation, a multiplicity of changes occurs including fever, leukocytosis, and quantitative and qualitative modification of a group of non-structurally related proteins present in blood and other biological fluids, collectively named acute phase proteins (APP; Ceciliani et al., 2012). Also as part of the APR of a mechanism for restricting the availability of iron is activated, in which some APP such as transferrin, lactoferrin, haptoglobin and ceruloplasmin are involved (Schaible and Kaufmann, 2004).

In this context, although clinical signs of Salmonellosis have been useful in monitoring the evolution of the disease, they can be difficult to quantify (Deignan et al., 2000). Therefore, the study of changes in blood serum contents, such as iron and APP concentrations, could help to identify and monitor newborn buffalo calves affected with Salmonellosis, especially as APP have been shown to be very useful biomarkers in various veterinary clinical situations (Eckersall and Bell, 2010).

In bovines, studies showed the serum protein profile (Silva et al., 2011) and iron concentrations (Silva et al., 2010) of infected Salmonella Dublin newborn calves and observed hypoferremia and increase of serum ceruloplasmin, haptoglobin, $\alpha 1$-acid glycoprotein and fibrinogen during the infection. In contrast, in buffaloes, there are few studies on APP dynamics (El-Deeb and Iacob, 2012; Tajik et al., 2012; Kumar et al., 2014), especially with simultaneous assessment of ferremic response (Horadagoda et al., 2002; Clemente et al., 2016). In regard to specific studies on APP dynamics and iron serum concentration changes in buffaloes with Salmonellosis, the literature is even more limited, and has only been accomplished with experimentally infected Salmonella Typhimurium newborn buffalo calves, where hypoferremia, decrease in blood serum transferrin concentrations and increase of blood serum ceruloplasmin and haptoglobin concentrations during the APR of the disease were noted (Clemente et al., 2016).

In cattle, $S$. Dublin is considered an adapted serotype, unlike $S$. typhimurium. Therefore, alterations in blood serum profile tend to be stonger and clinical signs tend to be more severe when $S$. Dublin is involved (Silva et al., 2008) and milder and less severe with $S$. Typhimurium (Ávila et al., 2011). However, although these serotypes are also the most widespread in buffalo herds, it is unclear whether they are adapted to buffaloes (Láu, 1999) and if the course of infection is the same as in cattle. This study was therefore conducted to evaluate clinical signs, acute phase protein (APP) dynamics and iron serum concentration changes during the acute phase response (APR) of $S$. Dublin experimentally infected Murrah buffalo calves.

\section{Materials and methods}

\subsection{Animals and experimental groups}

This research was approved by the Ethics Committee on Animal Use of Faculdade de Ciências Agrárias e Veterinárias, UNESP (Protocol n ${ }^{\circ}$ 010885-08).

To conduct the experiment, twelve Murrah buffalo calves (10-25 days of age), obtained from commercial herds in São Paulo state, Brazil, were randomly allocated to two experimental groups. The control group (CNT; $\mathrm{n}=6$ ): buffalo calves that orally received $10 \mathrm{~mL}$ of Brain Heart Infusion (BHI) broth. The infected group (INF; $n=6$ ): buffalo calves that were challenged orally with $10^{8} \mathrm{CFU}$ of $S$. Dublin strain suspended in $10 \mathrm{~mL}$ of BHI broth.

During the experimental period, calves were housed in individual suspended shelters $(1.30 \mathrm{~m} \times 1.50 \mathrm{~m} \times 1.35 \mathrm{~m}$ and $0.4 \mathrm{~m}$ above the ground) at "Laboratório de Apoio à Pesquisa do Departamento de Clínica e Cirurgia Veterinária, FCAV, UNESP, Jaboticabal, Brazil”, and fed four liters of cow's pasteurized fresh milk a day, as well as commercial feed, hay and water "ad libitum". Also during the experimental period, the cleaning and disinfection of buckets and shelters was performed twice a day with detergent and $2.5 \%$ sodium hypochlorite solution.

Before the calves were housed in individual suspended shelters, they were kept together with their lactating mothers and suckled colostrum "ad libitum" for a period of at least 3 consecutive days.

\subsection{S. Dublin inoculum preparation}

Inocula for induction of experimental infection was prepared from a $S$. Dublin sample (IOC record: 3101/03) originally isolated from feces of infected cattle during an outbreak of Salmonellosis. This strain is naturally resistant to nalidixic acid $\left(\mathrm{Nal}^{\mathrm{r}}\right)$ and was donated by "FIOCRUZ, Rio de Janeiro, Brazil (Centro de Referência de Enterobactérias do Departamento de Bacteriologia)". Inocula were prepared according to Fecteau et al. (2003). By using the Miles and Misra (1938), appropriate dilutions were made to obtain the required concentration of colonies/mL. After the concentration of colonies was determined, each animal was orally challenged with approximately $10^{8}$ CFU suspended in $10 \mathrm{~mL}$ of BHI broth using a sterile syringe.

\subsection{Bacteriological isolation from feces}

Rectal swabs were collected from each animal immediately before inoculation $(0 \mathrm{~h})$ and $24,48,72,96,120,144$ and $168 \mathrm{~h}$ after inoculation (HAI). Bacteriological culture for isolation of $S$. Dublin from the rectal swabs was performed according to recommendations of Santos et al. (2002). A multiplex PCR assay was also used for detection of the bacteria and also was performed according to recommendations of Itoh et al. (1997). Bacteriological culture and PCR were performed at "Laboratório de Apoio à Pesquisa do Departamento de Clínica e Cirurgia Veterinária, FCAV, UNESP, Jaboticabal, Brazil”.

\subsection{Physical examination}

Animals were submitted to physical examination before inoculation (0 h) and 12, 24, 36, 48, 60, 72, 84, 96, 108, 120, 132, 144, 156 and 168 HAI. Feces consistency and rectal temperature, two important symptoms characteristic of Salmonella infections were evaluated. Hyperthermia was considered in animals with rectal temperature above $40.0^{\circ} \mathrm{C}$. Feces consistency was determined, according to the severity of diarrhea, as: Score 0- normal feces consistency, Score 1 - mild diarrhea, Score 2 - moderate or severe diarrhea (Tremblay, 1990). Also, presence of blood and mucus in feces were evaluated. 


\subsection{Collection of blood samples}

Blood samples were collected from each animal immediately before inoculation $(0 \mathrm{~h})$ and $24,48,72,96,120,144$ and $168 \mathrm{HAI}$ by puncture of the jugular vein using a vacuum collection system. Blood samples were collected into siliconized plastic tubes containing EDTA, for fibrinogen analyses, and tubes without anticoagulant, for performing iron, total protein, total haptoglobin and 1-DE and 2-DE analyses. Blood serum samples were obtained by centrifugation $\left(10 \mathrm{~min}, 4^{\circ} \mathrm{C}, 1000 \times \mathrm{g}\right)$ of $10 \mathrm{ml}$ of blood collected in the siliconized vials without anticoagulant.

\subsection{Total protein, iron, fibrinogen and haptoglobin analysis}

Total blood serum protein (Biuret Method) and blood serum iron (modified method of Goodwin) concentrations were evaluated using commercial kits (Labtest Diagnóstica) and a semiautomatic spectrophotometer (Labquest, Labtest Diagnóstica). Fibrinogen content was determined by the heat precipitation method (Millar et al., 1971). Haptoglobin concentrations were analyzed on an ABX Pentra 400 (Horiba ABX SAS, Montpellier, France) by using a hemoglobin binding method developed by Eckersall et al. (1999).

All these analyses were performed at "Laboratório de Apoio à Pesquisa do Departamento de Clínica e Cirurgia Veterinária, FCAV, UNESP, Jaboticabal, Brazil" and Acute Phase Laboratory, Institute of Biodiversity, Animal Health \& Comparative Medicine, Garscube Campus, University of Glasgow, UK. For these variables, each sample was measured in duplicate. Duplicate results were only used when intra-assay coefficients of variation were less than $10 \%$. When above $10 \%$, further measurements were performed to assure the quality of the data.

\subsection{1-DE and 2-DE analysis}

1-DE analysis was performed at "Laboratório de Apoio à Pesquisa do Departamento de Clínica e Cirurgia Veterinária, FCAV, UNESP, Jaboticabal, Brazil". 2-DE analysis was performed at the Acute Phase Laboratory, Institute of Biodiversity, Animal Health \& Comparative Medicine, Garscube Campus, University of Glasgow, UK. For electrophoresis analysis, two replicas for each buffalo serum sample were performed. Duplicate results were only used when intra-assay coefficients of variation for each protein fraction analyzed were less than $10 \%$.

\subsubsection{1-DE analysis}

Band fraction separation of ceruloplasmin, $\beta$-haptoglobin, $\alpha$-haptoglobin and transferrin were obtained by performing SDS-PAGE, as proposed by Laemmli (1970). For this, serum concentrations of total protein were measured (Biuret Method) to calculate the final volume of sample that would be loaded on each lane. Since protein concentrations in the serum ranged from 46.3 to $108.6 \mu \mathrm{g} / \mu \mathrm{L}, 0.5 \mu \mathrm{L}$ of sample were loaded on each lane so that total protein amount would be of $50 \mu \mathrm{g}$. Therefore, equal volumes of sample and preparation solution (Proportions of preparation solution: $18.0 \mathrm{~mL}$ of deionized water, $10.0 \mathrm{ml}$ of $10 \%$ SDS, $4.0 \mathrm{~mL}$ of EDTA $0.5 \mathrm{M} \mathrm{pH} 8.3,5.0 \mathrm{~mL}$ of tris-phosphate, $3.0 \mathrm{~mL}$ of mercaptoethanol, $10.0 \mathrm{~mL}$ of glycerol and $5.0 \mathrm{mg}$ of Bromphenol Blue) were mixed and heated for $10 \mathrm{~min}$ on boiling water, and then transferred to the SDS-PAGE gel $(16 \times 20 \mathrm{~cm}$ gel, containing 18 lanes) that was previously assembled in the gel running tank. Prestained protein ladder with wide range (molecular weight from 6500 to $200,000 \mathrm{Da}$, Sigma-Aldrich S8445) was added in one of the lanes.

Electrophoresis was run at $80-90 \mathrm{~V}$ for $90 \mathrm{~min}$ and then at $100-110 \mathrm{~V}$, at room temperature, until the process was completed. Gels were stained for 1-2 hours in colloidal solution of $0.2 \%$ Coomassie brilliant blue after which the stain solution was discarded and distaining was carried out overnight using a solution of $10 \%(\mathrm{v} / \mathrm{v})$ acetic acid and $25 \%(\mathrm{v} / \mathrm{v})$ methanol.

Molecular weight (MW) of protein fractions were determined to verify that protein bands from samples from the control group were compared to the same molecular weight protein bands from samples from the infected groups. Therefore, by adding 12 proteins with known MW (Sigma-Aldrich S8445: 6500 Da; 14,200 Da; 20,000 Da; 24,000 Da; $29,000 \mathrm{Da} ; 36,000 \mathrm{Da}$; 45,000 Da; $55,000 \mathrm{Da} ; 66,000 \mathrm{Da} ; 97,000 \mathrm{Da}$; $116,000 \mathrm{Da} ; 200,000 \mathrm{Da}$ ) to each gel, it was possible, using computerassisted densitometry (CS-9301PC, Shimadzu Corporation), to create statistically valid MW reference curves and posteriorly calculate the MW of the protein fractions of each serum sample, after gel running was performed.

For calculating/estimating concentrations of protein fractions, computer-assisted densitometry (CS-9301PC, Shimadzu Corporation) was used. In this sense, the relative $\%$ of each protein fraction was calculated for each sample, and posteriorly band fraction concentrations $(\mathrm{g} / \mathrm{L})$ were estimated using the respective $\%$ and the total protein previously measured by the Biuret Method ( $\%$ x TP concentration/100).

\subsubsection{2-DE analysis}

Expression patterns of ceruloplasmin, $\beta$-haptoglobin, $\alpha$-haptoglobin and transferrin were obtained by performing isoelectric focusing followed by SDS-PAGE, as performed by Santana et al. (2018) for blood serum samples. Equal protein loading of $200 \mu \mathrm{g}$ was used, in all samples, for 2-DE protein separation, and samples were loaded in $11 \mathrm{~cm}, \mathrm{pH}$ 3-10 nonlinear IPG strips (BioRad, Hemel Hempstead, UK) according to manufacturer's instructions. Active rehydration and then isoelectric focusing were carried out on a Bio-Rad Protean IEF. Posteriorly, IPG strips were inserted horizontally on to the IPG well of a pre-cast IPG +1 well comb (containing the $4-15 \%$ T polyacrylamide gel) previously assembled in the gel running tank (Bio Rad, Criterion ${ }^{\mathrm{TM}}$ Vertical Electrophoresis Cell), and electrophoresis was run at $200 \mathrm{~V}$ for 40-45 min at room temperature. Gels were removed from the gel cassette and then stained for $1-2 \mathrm{~h}$ in colloidal solution of Coomassie brilliant blue stain G-250 dye $0.1 \%(\mathrm{w} / \mathrm{v}), 10 \%$ (v/v) acetic acid, $40 \%$ ( $\mathrm{v} / \mathrm{v})$ ethanol (Invitrogen, Manchester, UK) after which stain solution was discarded and destaining carried out overnight using a solution of $10 \%(\mathrm{v} / \mathrm{v})$ acetic acid and $25 \%(\mathrm{v} / \mathrm{v})$ methanol. Image of gels were scanned using a UMAX Power Look III scanner and software (Hamrick software, USA). Gel images were then processed and analyzed using SameSpot computer program (version 4.6, Totallab, UK), to highlight protein spots that showed significant and reproducible modulation between blood serum protein samples of interest.

\subsection{Protein identification by trypsin digestion and LC/ESI-MS/MS analyses}

Enzymatic digestion of proteins selected from bands and spots from 1-DE and 2-DE were performed. Tryptic peptides were generated and extracted from gel pieces as previously described (Daneshvar et al., 2012), and were analyzed by LC/ESI-MS/MS, using a Bruker Amazon ion trap (Amazon speed ETD) instrument to produce MS and MS/MS data. The MS data obtained was compared with bovine and mammalian sequences in the NCBI predicted protein database using an in-house Mascot search engine. These analyzes were performed at Glasgow Polyomics Facility, University of Glasgow, Glasgow, United Kingdom.

\subsection{Statistical analysis}

For the variables from 1-DE analysis (ceruloplasmin, $\beta$-haptoglobin, $\alpha$-haptoglobin and transferrin) and total protein, iron and fibrinogen, $\mathrm{T}$ unpaired test was applied to evaluate the effects of groups (CNT x INF). For the same variables, ANOVA for repeated measures was applied to evaluate the effect of HAI (before inoculation x 24 to $168 \mathrm{HAI}$ ), and means were compared by Tukey's test using a significance level of $5 \%$.

For the variables from 2-DE analysis (ceruloplasmin, $\beta$-haptoglobin, $\alpha$-haptoglobin and transferrin) and haptoglobin (hemoglobin binding 
method), T paired test was applied to evaluate the effect of HAI (before inoculation x $168 \mathrm{HAI}$ ).

Pearson correlation test was performed, using 8 time-points from 1DE results $(0,24,48,72,96,120,144$ and $168 \mathrm{HAI})$, to determine degree of correlation (Pearson $r$ ) between positive APP $\beta$-haptoglobin, $\alpha$-haptoglobin, ceruloplasmin and fibrinogen.

\section{Results}

\subsection{Clinical signs of Salmonellosis during the infection period}

Salmonella was not isolated at any time point of the experiment in buffalo calves from the CNT. The first bacterium isolation (cultures and PCR) occured in the INF $24 \mathrm{~h}$ after buffalo calves were inoculated with the $S$. Dublin strain. At $72 \mathrm{HAI}$, the bacteria was detected in the feces of all animals inoculated and isolation persisted until the end of the experiment.

Hyperthermia was considered in animals with rectal temperature above $40.0^{\circ} \mathrm{C}$. Rectal temperature of buffalo calves from CNT were stable and ranged from $37.5^{\circ} \mathrm{C}$ to $39.7^{\circ} \mathrm{C}$ throughout the experimental period. In calves from the INF, hyperthermia was first observed $60 \mathrm{HAI}$. Episodes of hyperthermia were observed until 132 HAI. Rectal temperature then returned to physiological values in all animals at $144 \mathrm{HAI}$ and until the end of the experiment (Fig. 1A).

A

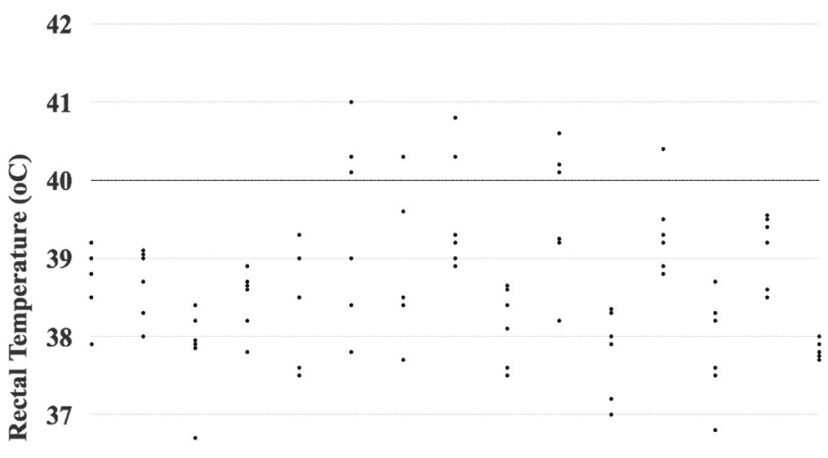

36

35

$\begin{array}{lllllllllllllll}0 & 12 & 24 & 36 & 48 & 60 & 72 & 84 & 96 & 108 & 120 & 132 & 144 & 156 & 168\end{array}$

Hours post-inoculation

B

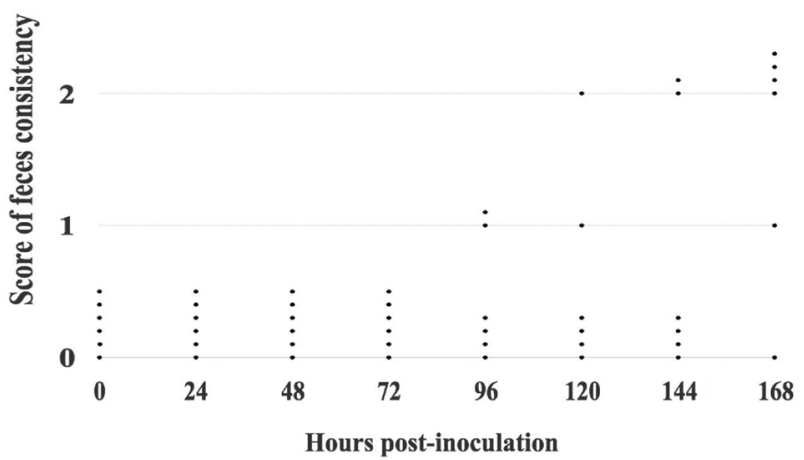

Fig. 1. Dispersion graph of rectal temperature (A) and score of feces consistency (B) from the six buffalo calves experimentally infected with $10^{8} \mathrm{CFU}$ of Salmonella Dublin (G2). Above the dotted horizontal line indicates number of animals with hyperthermia (A). Score 0: normal feces consistency, Score 1: mild diarrhea, Score 2: moderate or severe diarrhea (B).
Normal feces consistency (score 0), not characteristic of salmonellosis (absence of mucus and blood) were observed during the experiment in CNT. In the INF, characteristic salmonellosis mild diarrhea (score 1), with presence of mucus and blood, started 96 HAI. After $96 \mathrm{~h}$, episodes of severe diarrhea (score 2) appeared and a peak occurred at 168 HAI (Fig. 1B).

\subsection{APP and iron dynamics during the infection period}

After performing 1-D and 2-D electrophoresis, protein bands and spots were identified using LC/ESI-MS/MS and NCBI predicted protein database (Table 1). Positions of APP in the gels are illustrated in Fig. 2. Results for APP and serum iron during the infection are given in Tables 1 and 2 and Fig. 3. Pearson correlation coefficient has been calculated to highlight degree of correlation between APP during the infection process and are illustrated in Table 3. Percentage of increase, over baseline values, of APP and serum iron concentrations in the INF, during the infection, are illustrated in Table 1 and Fig. 4.

Two protein bands ( 3 and 4 ) and three protein spots ( 8,9 and 10) were identified as haptoglobin, a positive APP. Band 3 and spots 4 and 5 , between $35-40 \mathrm{kDa}$, is $\beta$-haptoglobin. Band 4 and spot 6 , between $15-25 \mathrm{kDa}$, is $\alpha$-haptoglobin (Table 1, Fig. 2).

1 -DE results showed that serum $\beta$-haptoglobin and $\alpha$-haptoglobin concentrations had progressive and major increase in the INF during the infection and were significantly increased 48 HAI, by $204 \%$ $(p=0.008)$ and $184 \%(p=0.022)$, respectively, when compared to before inoculation (Table 2, Figs. 3 and 4). After $48 \mathrm{~h}$, these protein fractions continued to increase and presented their highest concentrations at 120, 144 and 168 HAI. At these time-points, $\beta$-haptoglobin and $\alpha$-haptoglobin concentrations were increased by $498 \%(\mathrm{p}=0.012)$ and $431 \%(\mathrm{p}=0.011) 120$ HAI, $421 \%(\mathrm{p}=0.029)$ and $400 \%(\mathrm{p}=0.038)$ $144 \mathrm{HAI}$, and $492 \%(\mathrm{p}=0.019)$ and $523 \%(\mathrm{p}=0.028) 168 \mathrm{HAI}$, respectively, when compared to before inoculation. As a consequence of the progressive increase of $\beta$-haptoglobin and $\alpha$-haptoglobin concentrations during the infection, diferences between the INF and CNT were observed at 72, 120, 144 and 168 HAI for $\beta$-haptoglobin (Table 2 and Fig. 3; p $=0.020, p<0.0001, p=0.003$ and $p<0.0001$, respectively) and at 72, 96, 120 and $168 \mathrm{HAI}$ for $\alpha$-haptoglobin (Table 2 and Fig. $3 ; \mathrm{p}=0.025, \mathrm{p}=0.035, \mathrm{p}=0.028$ and $\mathrm{p}=0.033$, respectively).

2-DE results also showed a significant increase of $\beta$-haptoglobin and $\alpha$-haptoglobin between 0 and 168 HAI (Table 1 ). At 168 HAI, spots 4 and 5 , identified as $\beta$-haptoglobin, presented significantly increased expression, by $693 \%(\mathrm{p}=0.0006)$ and $580 \%(\mathrm{p}=0.0003)$, respectively, when compared to before inoculation. In the same way, spot 6 , identified as $\alpha$-haptoglobin, also presented significantly increased expression 168 HAI $(714 \%, p=0.040)$. Additionally, analysis performed by the hemoglobina binding method validated results from 1-DE and 2$\mathrm{DE}$, since results from this technique showed that total haptoglobin concentrations increased significantly between 0 and $168 \mathrm{HAI}$, by $1339 \%(\mathrm{p}<0.0001)$.

The positive APP ceruloplasmin was identified between 130-170 kDa (Table 1, Fig. 2). 1-DE results showed that in the INF, this protein increased significantly $48 \mathrm{HAI}(\mathrm{p}=0.034$, increased in $42 \%$ when compared to before inoculation) and showed its highest concentration peaks at 120, 144 and 168 HAI with increases of $133 \%$ $(\mathrm{p}=0.022), 123 \%(\mathrm{p}=0.025)$ and $107 \%(\mathrm{p}=0.002)$ compared to before inoculation, respectively. Therefore, 48 HAI $(p=0.005)$ and at 120 ( $\mathrm{p}<0.0001), 144$ ( $<<0.0001)$ and 168 HAI $(\mathrm{p}<0.0001)$, diferences between groups occured (Table 2, Figs. 3 and 4).

2-DE analysis was able to validate results from 1-DE since results from 2-DE also showed a significant increase of ceruloplasmin between 0 and $168 \mathrm{HAI}$ (Table 1). At $168 \mathrm{HAI}$, spots 1 and 2, identified as ceruloplsmin, presented significantly increased expression, by $218 \%$ ( $\mathrm{p}=0.0153)$ and $85 \%(\mathrm{p}=0.0143)$, respectively, when compared to before inoculation. 
Table 1

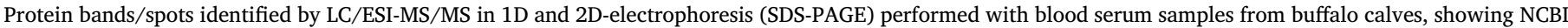

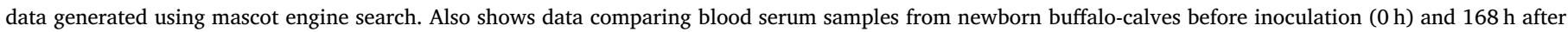
inoculation with $10^{8} \mathrm{CFU}$ of $S$. Dublin.

\begin{tabular}{|c|c|c|c|c|c|c|c|c|c|}
\hline \multirow[t]{2}{*}{$\begin{array}{l}\text { Band/Spot } \\
\text { ID }\end{array}$} & \multirow[t]{2}{*}{$\begin{array}{l}\text { Protein identification } \\
\text { (Accession number, organism) }\end{array}$} & \multirow[t]{2}{*}{$\begin{array}{l}\text { Protein MASCOT } \\
\text { Score }^{\mathrm{a}}\end{array}$} & \multirow[t]{2}{*}{ Matches $^{\mathrm{b}}$} & \multirow[t]{2}{*}{ Sequences $^{c}$} & \multirow[t]{2}{*}{ Anova $(p)^{d}$} & \multirow{2}{*}{$\begin{array}{l}\text { Fold change } \\
168 \mathrm{~h} / 0 \mathrm{~h}\end{array}$} & \multicolumn{3}{|c|}{$\begin{array}{l}\text { Protein expression or concentration } \\
\text { (Average } \pm S D \text { ) }\end{array}$} \\
\hline & & & & & & & $\mathrm{Oh}$ & $168 \mathrm{~h}$ & Units \\
\hline 1 & Ceruloplasmin (gi|594079008, BB) & $173(0.10)$ & $28(4)$ & $19(4)$ & 0.0020 & $+2.07(107.0 \%)$ & $0.57 \pm 0.33$ & $1.18 \pm 0.33$ & $\mathrm{~g} / \mathrm{L}$ \\
\hline 2 & Serotransferrin (gi|594054424, BB) & $1612(0.70)$ & $90(24)$ & $36(14)$ & 0.8750 & $-1.13(-11.6 \%)$ & $3.78 \pm 1.61$ & $3.34 \pm 0.80$ & $\mathrm{~g} / \mathrm{L}$ \\
\hline 3 & $\beta$-Haptoglobin (gi|595763483, BT) & $1085(1.21)$ & $114(35)$ & $22(12)$ & 0.0190 & + $5.91(491.4 \%)$ & $0.47 \pm 0.77$ & $2.78 \pm 2.18$ & $\mathrm{~g} / \mathrm{L}$ \\
\hline 4 & $\alpha$-Haptoglobin (gi|283467275, BB) & $471(0.37)$ & $25(11)$ & $9(5)$ & 0.0280 & $+6.23(523.0 \%)$ & $0.13 \pm 0.28$ & $0.81 \pm 0.67$ & $\mathrm{~g} / \mathrm{L}$ \\
\hline 5 & Ceruloplasmin (gi|296,491,101, BT) & $201(0.16)$ & $17(6)$ & $10(6)$ & 0.0153 & $+3.21(218.2 \%)$ & $0.65 \pm 0.15$ & $2.09 \pm 0.20$ & $\operatorname{ANV}\left(x 10^{6}\right)$ \\
\hline 6 & Ceruloplasmin (gi|296,491,101, BT) & $42(0.03)$ & $5(1)$ & $3(1)$ & 0.0143 & $+1.86(85.3 \%)$ & $0.45 \pm 0.22$ & $0.84 \pm 0.01$ & $\operatorname{ANV}\left(x 10^{6}\right)$ \\
\hline 7 & Serotransferrin (gi| $594,054,424, \mathrm{BB})$ & $2325(1.78)$ & $202(69)$ & $37(25)$ & 0.9270 & $-1.03(-3.15 \%)$ & $6.33 \pm 1.86$ & $6.13 \pm 2.00$ & $\operatorname{ANV}\left(x 10^{6}\right)$ \\
\hline 8 & $\beta$-Haptoglobin (gi| $595,763,483, \mathrm{BB})$ & $1043(1.21)$ & $116(30)$ & $21(12)$ & 0.0006 & $+7.93(693.4 \%)$ & $0.12 \pm 0.04$ & $0.97 \pm 0.14$ & $\operatorname{ANV}\left(x 10^{6}\right)$ \\
\hline 9 & $\beta$-Haptoglobin (gi| $595,763,483, \mathrm{BB}$ ) & $1142(1.07)$ & $138(43)$ & $21(11)$ & 0.0003 & $+6.80(580.0 \%)$ & $0.14 \pm 0.05$ & $0.98 \pm 0.11$ & $\operatorname{ANV}\left(x 10^{6}\right)$ \\
\hline 10 & a-Haptoglobin (gi| $595,763,483, \mathrm{BB})$ & $480(0.30)$ & $35(13)$ & $7(4)$ & 0.0400 & $+8.14(714.2 \%)$ & $0.10 \pm 0.05$ & $0.85 \pm 0.21$ & $\operatorname{ANV}\left(x 10^{6}\right)$ \\
\hline- & Total Haptoglobin ${ }^{\mathrm{e}}$ & - & - & - & $<0.0001$ & $+14.4(1339.4 \%)$ & $0.38 \pm 0.53$ & $5.47 \pm 1.69$ & $\mathrm{~g} / \mathrm{L}$ \\
\hline
\end{tabular}

BB, Bubalus bubalis; BT, Bos taurus; ANV, Average Normalized Volumes; SD, Standard Deviation; ID, Identification.

a The number in parenthesis indicates the Exponentially Modified Protein Abundance Index (emPAI).

b Total number of peptide matches. The number in parenthesis indicates the number of matches above the significance threshold ( $\mathrm{p}<0.05$ ).

c Total number of distinct peptide sequences. The number in parenthesis indicates the number of matches above the significance threshold ( $\mathrm{p}<0.05$ ).

d Statistical difference pointed by ANOVA analyses generated by SameSpot program ( $\mathrm{p}<0.05$ ), showing differently expressed spots in bold.

e Hemoglobin binding method: Based on the method of Eckersall et al. (1999) on an ABX Pentra 400, Horiba ABX SAS, Montpellier, France.

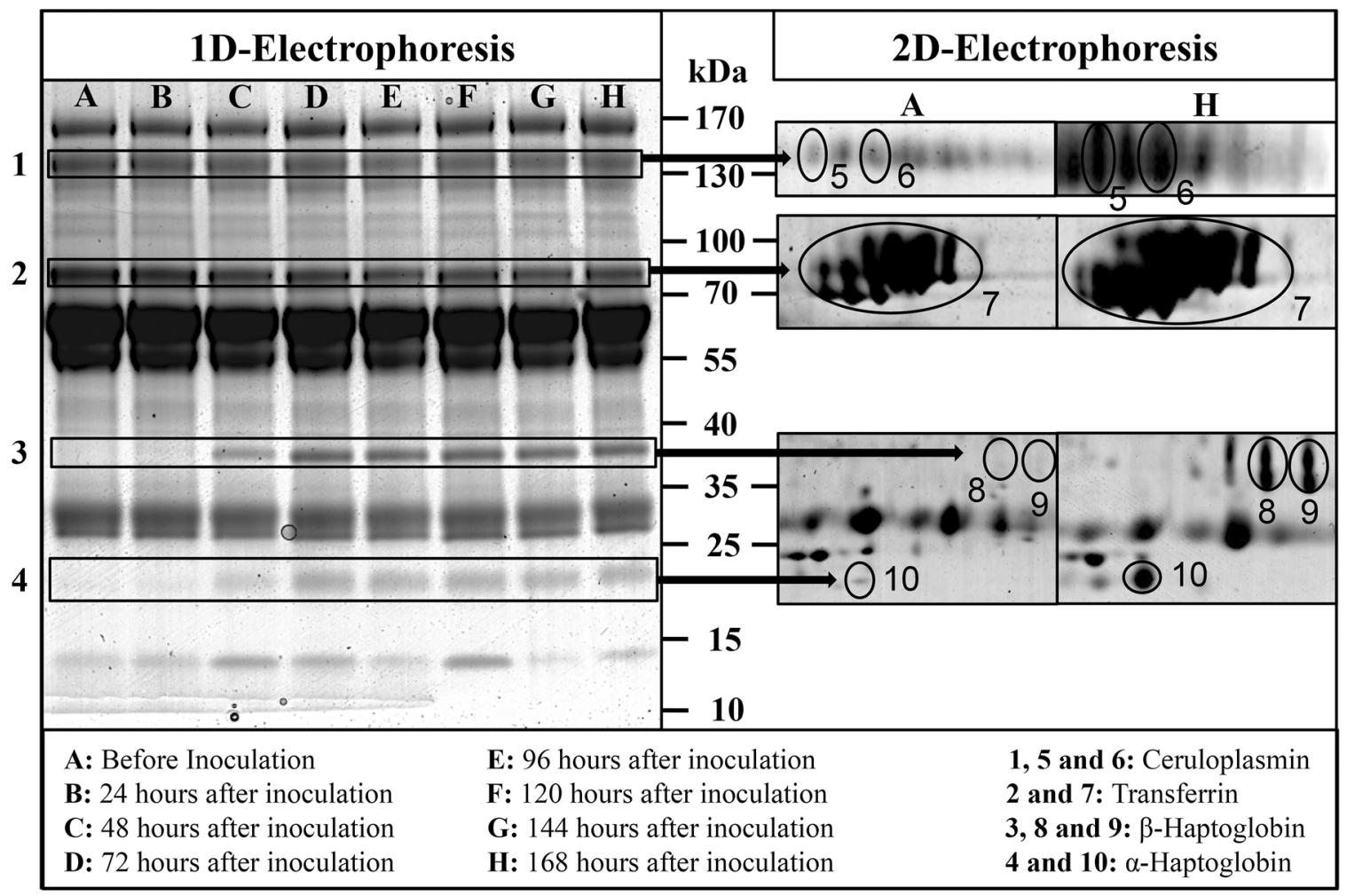

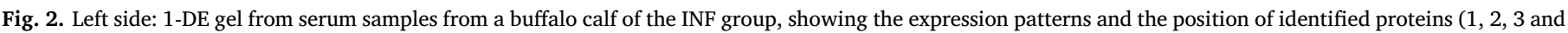

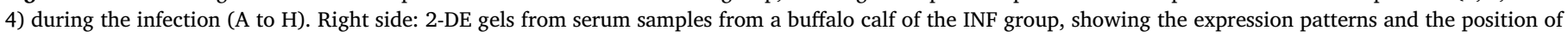
identified proteins (5, 6, 7, 8, 9 and 10) before the inoculation (A) and $168 \mathrm{HAI}(\mathrm{H})$.

Plasma fibrinogen concentrations, another positive APP determined by the heat precipitation method, increased significantly by $78 \%$ $(\mathrm{p}=0.012)$ at $96 \mathrm{HAI}$, compared to before inoculation, and peak concentrations were found at 120 and $168 \mathrm{HAI}$, where concentrations were increased by $114 \%(\mathrm{p}=0.002)$ and $103 \%(\mathrm{p}=0.015)$, respectively (Table 2, Figs. 3 and 4). Although peak concentrations occured between 120 and $168 \mathrm{HAI}$, significant diferences between groups were found only at the highest peak concentration, $120 \mathrm{HAI}(\mathrm{p}=0.001)$.

Iron serum concentrations decreased between $0 \mathrm{~h}$ and $72 \mathrm{HAI}$, and significantly decreased 33\% $(\mathrm{p}=0.015)$ and $37 \%(\mathrm{p}=0.029)$ at 24
HAI and $72 \mathrm{HAI}$, respectively, when compared to before inoculation. After this initial decrease, iron concentrations restored between 96 and $168 \mathrm{HAI}$, but at $168 \mathrm{~h}$ still tended to be below concentrations measured before the inoculation. (Table 2, Figs. 3 and 4).

The negative APP transferrin was identified between $70-100 \mathrm{kDa}$ (Table 1, Fig. 2). In the INF, 1-DE results showed that transferrin concentrations decreased between 72 and 120 HAI. Therefore, at the lowest concentration point, $120 \mathrm{HAI}$, transferrin was significantly lower then before inoculation $(23 \%$ lower, $\mathrm{p}=0.047)$ and than 24 HAI $(31 \%$ lower, $\mathrm{p}=0.014$ ). Also, $72 \mathrm{HAI}$, transferrin concentrations were lower 


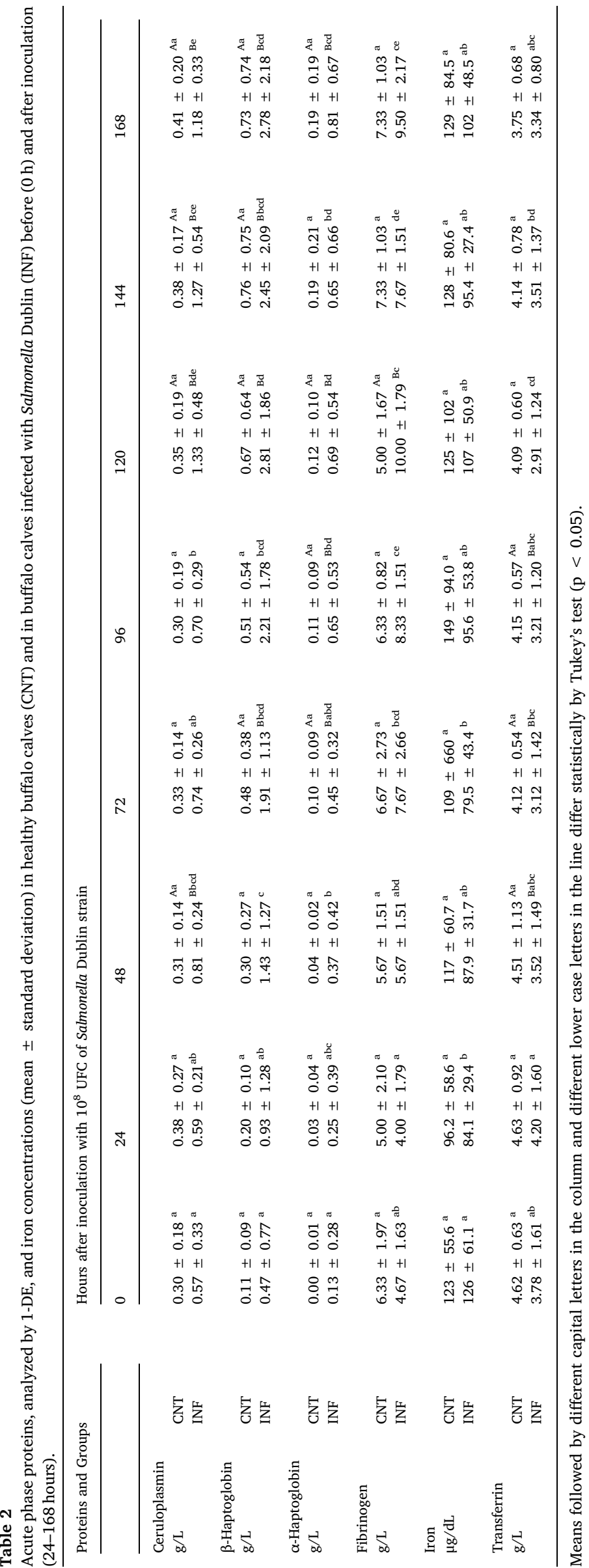




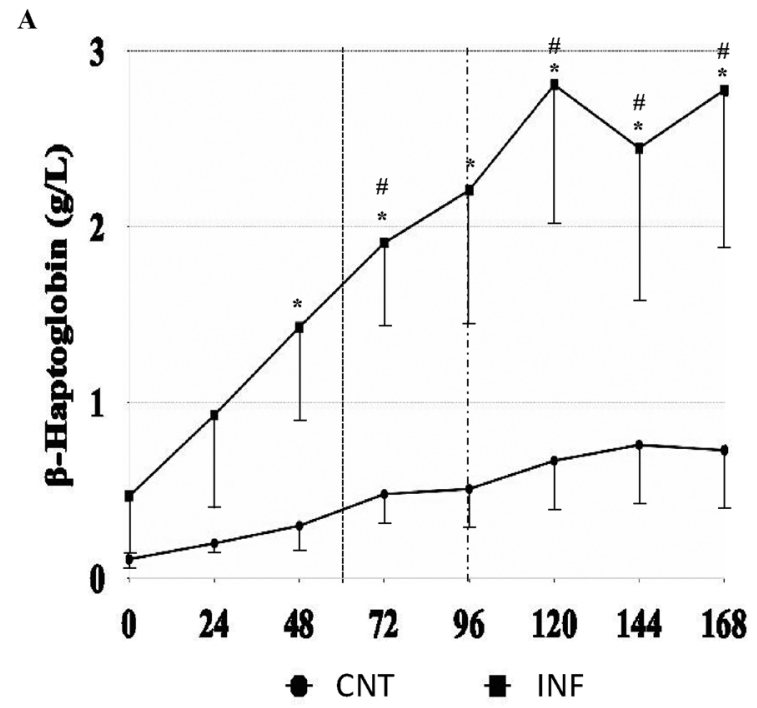

B

C
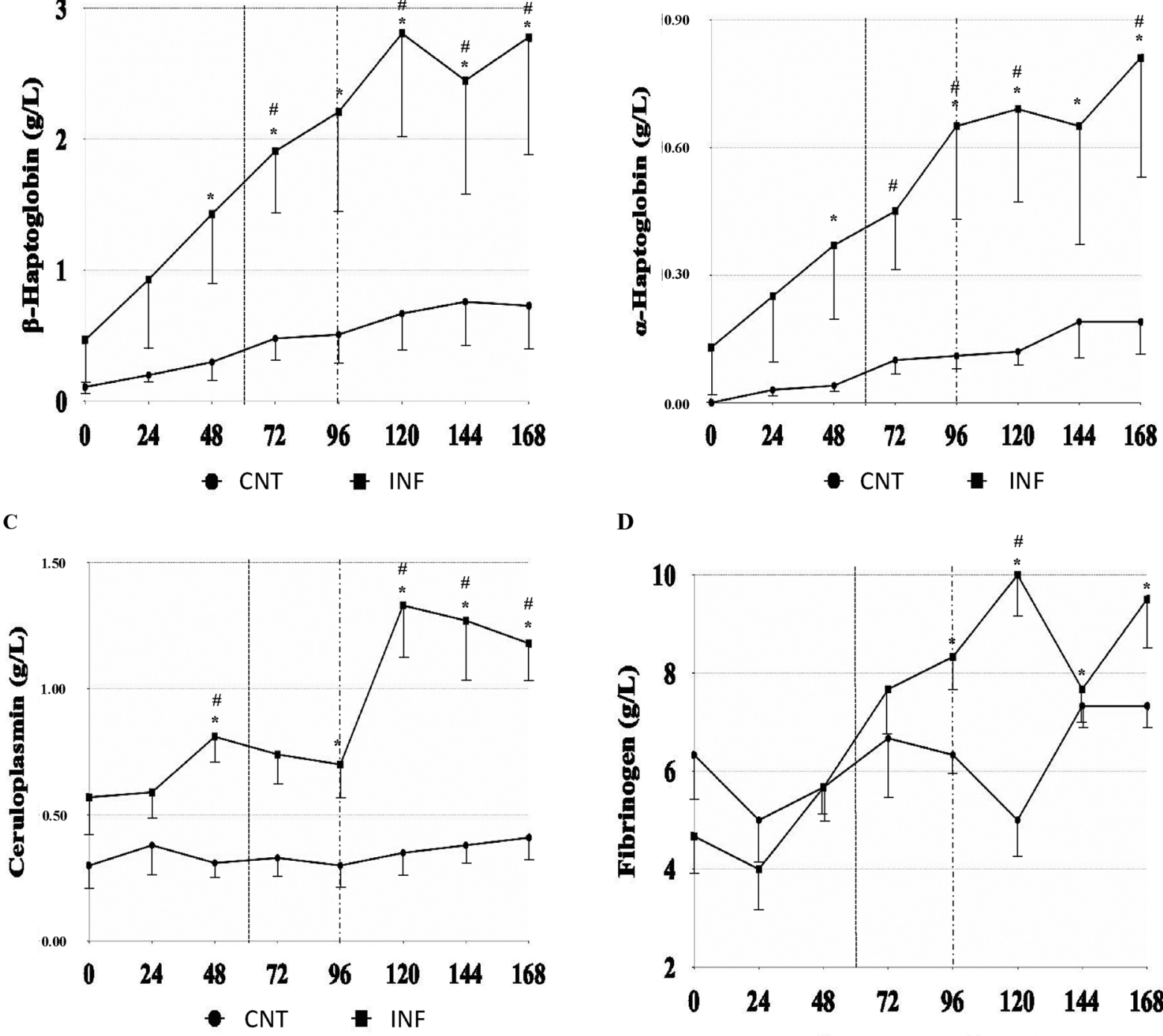

D

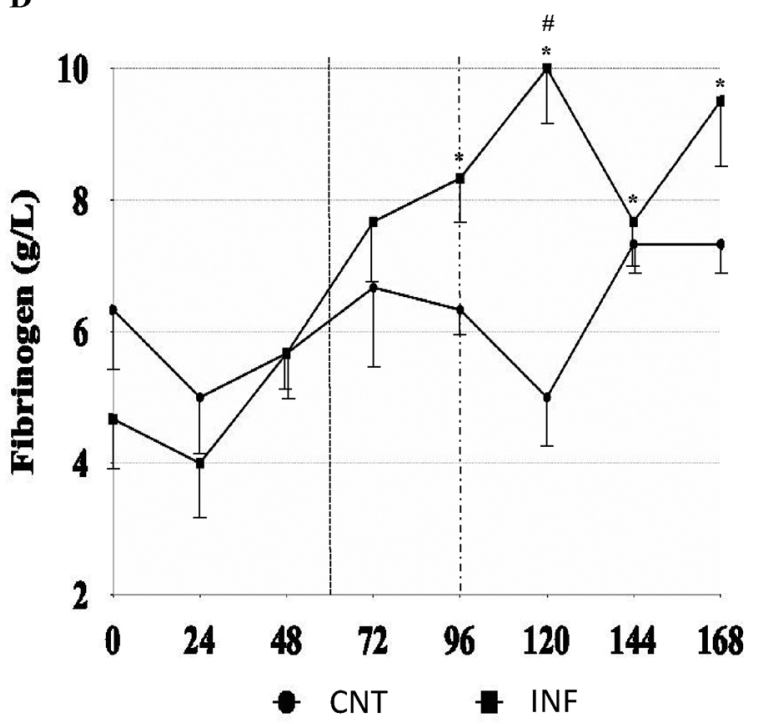

E

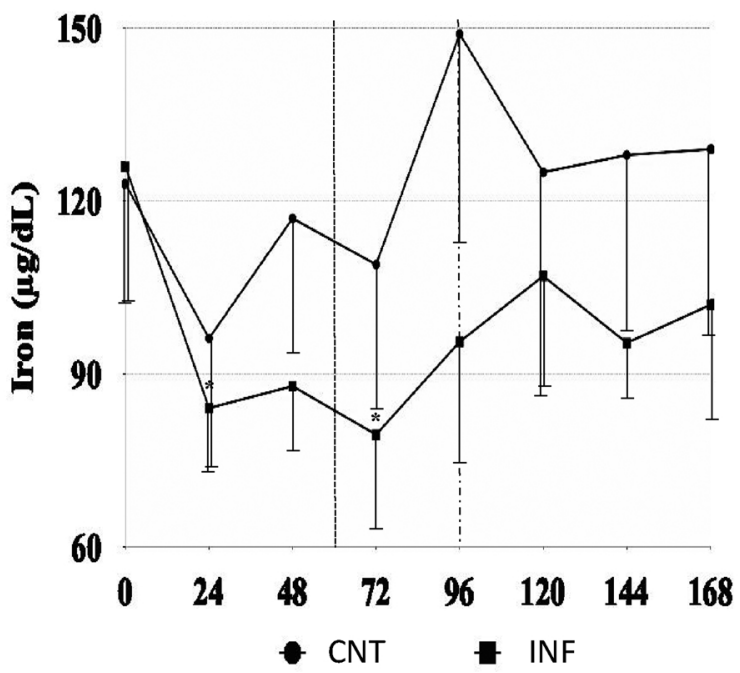

F

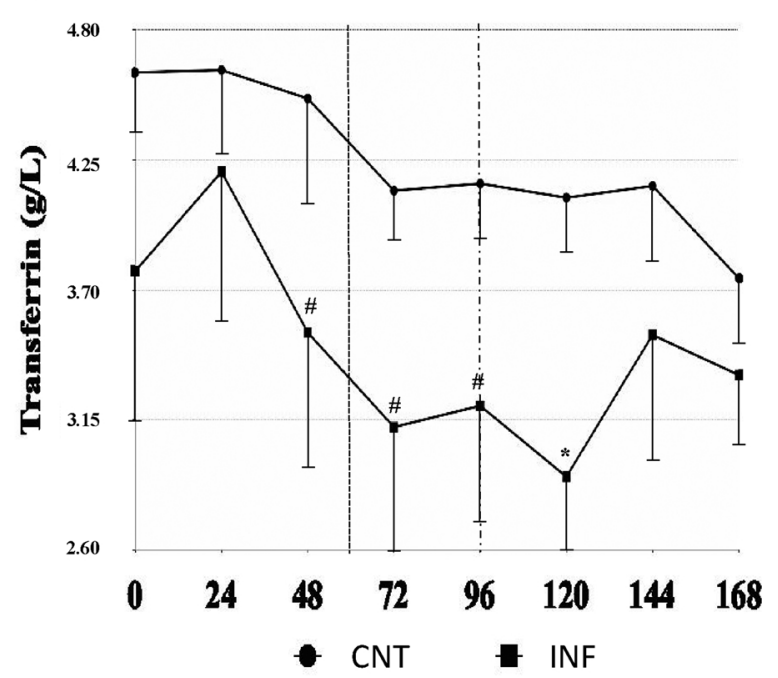

Fig. 3. Results from 1-DE analysis showing concentrations, with standard error bars, of $\beta$-haptoglobin (A), $\alpha$-haptoglobin (B), ceruloplasmin (C), fibrinogen (D), iron (E) and transferrin (F) from serum samples of buffalo calves uninfected (CNT) and experimentally infected with $10^{8} \mathrm{CFU}$ of $S$. Dublin (INF) before inoculation ( $0 \mathrm{~h}$ ) and until 168 HAI. The dotted vertical lines indicate the onset of episodes of hyperthermia (first line) and diarrhea (second line) in animals from INF. Asterisks indicate statistically significant differences from the respective baseline value $(0 \mathrm{~h})\left({ }^{*} \mathrm{P}<0.05\right)$. Number signs indicate statistically significant differences from the value obtained in the $\mathrm{CNT}$ at the same time $(\# \mathrm{P}<0.05)$. 
Table 3

Pearson correlation test between positive APP in blood serum from buffalo calves infected with Salmonella Dublin (G2), analyzed using results of 1-DE, from 0 to $168 \mathrm{~h}$ after inoculation.

\begin{tabular}{lll}
\hline Variables Compared & Pearson $\mathrm{r}^{\mathrm{a}}$ & P value (two-tailed) \\
\hline$\beta$-Haptoglobin vs $\alpha$-Haptoglobin & 0.98 & $<0.0001^{*}$ \\
$\beta$-Haptoglobin vs Ceruloplasmin & 0.85 & $0.0079^{* *}$ \\
$\beta$-Haptoglobin vs Fibrinogen & 0.91 & $0.0003^{*}$ \\
$\alpha$-Haptoglobin vs Ceruloplasmin & 0.80 & $0.0173^{*}$ \\
$\alpha$-Haptoglobin vs Fibrinogen & 0.93 & $0.0008^{*}$ \\
Ceruloplasmin vs Fibrinogen & 0.77 & $0.0257^{*}$ \\
\hline
\end{tabular}

* Significant correlation $(\mathrm{P}<0.05)$.

${ }^{\text {a }}$ Pearson $\mathrm{r}$ between $0.70-1.00$ (very strong positive correlation).

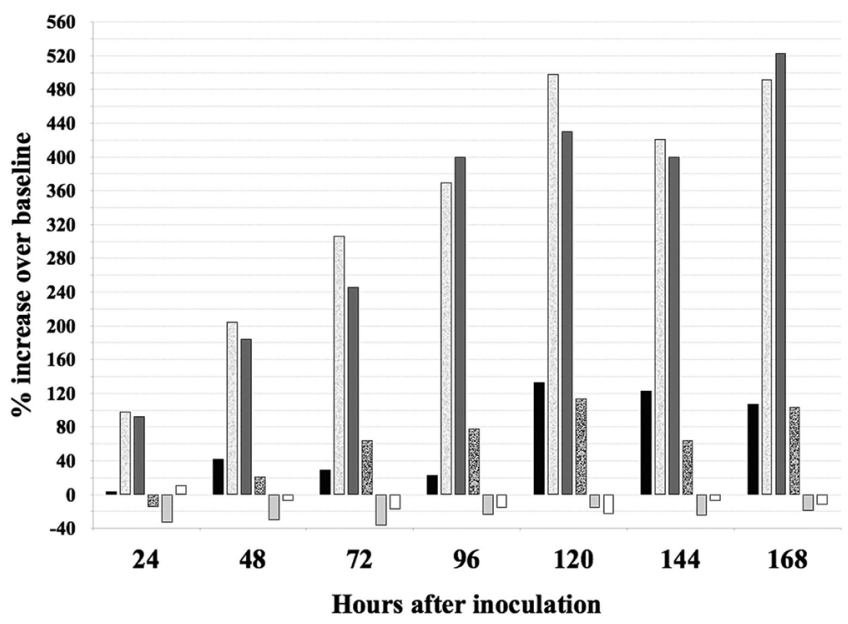

Ceruloplasmin $\square \beta$-Haptoglobin $\square \alpha$-Haptoglobin

Fibrinogen $\quad$ Iron $\quad \square$ Transferrin

Fig. 4. Percentage of increase (positive values) or decrease (negative values) of APP, performed by 1-DE analysis, and iron concentrations comparing HAI (24, $44,72,96,120,144$ and $168 \mathrm{~h}$ ) to before inoculation $(0 \mathrm{~h})$ in blood serum of buffalo calves experimentally infected with $10^{8}$ CFU of Salmonella Dublin (G2). Percentage of increase or decrease in relation to before inoculation (reference moment) is included on the left axis.

than 24 HAI $(26 \%$ lower, $p=0.012)$. As a consequence of decreased transferrin concentrations between 72 and $120 \mathrm{HAI}$, diferences between groups were found at 72 and 96 HAI ( $p=0.045$, and $p=0.027$, respectively) (Table 2, Figs. 3 and 4).

2-DE analysis showed that expression patterns of transferrin (spot 3) comparing $0 \mathrm{~h}$ and $168 \mathrm{HAI}$ were similar, the same as found by performing 1-DE, evidencing that, although transferrin values declined between 72 and $96 \mathrm{HAI}$, as shown by 1-DE analysis, these values were restored at the end of the experiment (Table 2, Figs. 3 and 4).

The positive APP $\beta$-haptoglobin, $\alpha$-haptoglobin, ceruloplasmin, and fibrinogen increased during the infection and therefore Pearson correlation coefficient (Pearson $\mathrm{r}$ ), using 8 time-points from 1-DE results, showed significant and very strong positive correlation between the proteins in the INF. The best correlation was between $\beta$ and $\alpha$-haptoglobin fractions. These fractions also presented better correlation to fibrinogen then to ceruloplasmin, although all correlations were significant and very strong. The lowest degree of correlation occurred between ceruloplasmin and fibrinogen (Table 3).

\section{Discussion}

The inoculation of $10^{8} \mathrm{CFU}$ of $S$. Dublin was effective in inducing clinical signs of salmonellosis such as hyperthermia and diarrhea (Fig. 1). Additionally, Salmonella was detected in the feces of all inoculated animals after $72 \mathrm{~h}$ of infection and isolation persisted until the end of the experiment.

The APR is part of the early-defence or innate immune system, which is triggered by different stimuli including trauma, infection, stress, neoplasia, and inflammation (Cray et al., 2009). This complex systemic reaction results in a rapid multiplicity of changes distant from the site of injury, and includes fever, leukocytosis and modification of APP present in blood and other biological fluids (Ceciliani et al., 2012). In the infected calves, $\beta$-haptoglobin and $\alpha$-haptoglobin fractions behaved as positive APP and were increased $48 \mathrm{HAI}$ (Table 2, Fig. 3), as showed by 1-DE results. Therefore, these protein fractions showed an acute response to infection, and also importantly, before the onset of clinical signs, since the first signs of hyperthermia and diarrhea started 60 and 96 HAI, respectively (Fig. 1).

Clemente et al. (2016), performing 1-DE for studying buffalo calves infected with $S$. Typhimurum also observed rapid response of $\beta$-haptoglobin, significantly increased 72 HAI. Therefore, the results described in our work showed that $\beta$-haptoglobin had a more rapid response to $S$. Dublin infection when compared with $S$. Typhimurum infection in work of Clemente et al. (2016).

$\beta$-haptoglobin and $\alpha$-haptoglobin concentrations continued to increase during infection and showed a very strong positive correlation to each other (Table 3), with highest peaks of concentration/expression patterns occuring between 120 and $168 \mathrm{HAI}$, as showed by 1-DE and 2DE results (Tables 1 and 2, Figs. 3 and 4). In this sense, although $\beta$ haptoglobin had a quicker initial response to $S$. Dublin infection, in our work, compared with $S$. Typhimurium infection in work of Clemente et al. (2016), the dynamics of this protein fraction during the rest of the infection showed that it increased similarly thereafter in both studies.

The highest concentration peaks of $\beta$-haptoglobin and $\alpha$-haptoglobin (120-168 HAI) (Tables 1 and 2, Fig. 3) was found at the same time as the highest incidence of severe diarrhea (Figs. 1B).Albayrak and Kabu (2016), studying bovine calves with diarrhea, verified that in diarrheic calves haptoglobin concentrations were almost 30 times higher then non-diarrheic calves. This was especially noticeable in bovine calves infected with Salmonella, where significant increases in haptoglobin concentrations occurred in all animals that presented diarrhea (Deignan et al., 2000). This is likely to be because $S$. Dublin settles in the digestive system, especially in the terminal portions of the ileum and cecum, inducing hypersecretion in the intestine and marked local inflammation with destruction of enterocytes and disruption of mucosal integrity (Radostits et al., 2007). These changes trigger an APP production and, among other symptoms, also induce profuse diarrhea (Fagiolo et al., 2005).

Moreover, in the circulation haptoglobin is present as a tetramer of two subunits of $\beta$-haptoglobin and two subunits of $\alpha$-haptoglobin so it is expected that there should be a strong positive correlation as found by 1-DE results (Table 3). As the molecular weights of the subunits differ with $\beta$-haptoglobin being larger with $\mathrm{MW}$ of $40 \mathrm{Kd}$ and $\alpha$-haptoglobin at a MW of $12 \mathrm{Kda}$ (in bovine) the relative concentrations of the subunits found here by using 1-DE analysis (Table 2) are also expected.

In the INF, ceruloplasmin also behaved as a positive APP and significantly increased by $48 \mathrm{HAI}$, as shown by the 1-DE results (Table 2, Fig. 3). Therefore, this protein fraction also showed a rapid response to infection, and also importantly, before the onset of clinical signs (60 to 96 HAI) (Fig. 1). Clemente et al. (2016), studying buffalo calves infected with $S$. Typhimurum, also observed a rapid response from ceruloplasmin, which was also significantly increased 48 HAI. Moreover, ceruloplasmin concentrations continued to increase during infection and showed its highest concentration/expression pattern peaks between 120 and $168 \mathrm{HAI}$, as shown by 1-DE and 2-DE results, the same time as $\beta$-haptoglobin and $\alpha$-haptoglobin concentrations also peaked (Tables 1 and 2, Figs. 3 and 4). These results were higher when compared to $S$. Typhimurum infection (Clemente et al., 2016), where ceruloplasmin also increased progressively during the APR of the infection.

As shown by 1 -DE results, $\beta$-haptoglobin and $\alpha$-haptoglobin initial 
responses to infection was stronger than ceruloplasmin since at $48 \mathrm{HAI}$, $\beta$ and $\alpha$-haptoglobin were increased in $204 \%$ and $185 \%$, respectively, against $42 \%$ for ceruloplasmin, when compared to before inoculation (Fig. 4). This continued throughout the experiment since $\beta$ and $\alpha$ haptoglobin continued to proportionally increase more than ceruloplasmin at peak points, 120, 144 and $168 \mathrm{HAI}$, as showed by 1-DE and 2-DE results (Tables 1 and 2, Fig. 4). Similar data was verified by Clemente et al. (2016) in $S$. Typhimurium infected buffalo calves, where haptoglobin concentrations increased at a maximum of $476 \%$ against $85 \%$ for ceruloplasmin, when compared to before the inoculation. Haptoglobin is a major APP in ruminants (Eckersall et al., 2001; Eckersall and Bell, 2010; Ceciliani et al., 2012) and is also considered a good indicator of inflammation in buffaloes (Khan et al., 1997). In bovine and buffaloes, increases in serum haptoglobin have been positively correlated with the severity of clinical signs of salmonellosis (Deignan et al., 2000; Silva et al., 2011; Clemente et al., 2016). Therefore, considering our findings and other published studies, all indicates that this protein can be a useful non-specific biomarker of Salmonella spp. infection not just in bovine, but also in buffaloes.

Fibrinogen, a moderate APP in ruminants (Ceciliani et al., 2012), is considered a good indicator of inflammation in buffaloes (Khan et al., 1997). In the INF, fibrinogen behaved as a positive APP, but only significantly increased by 96 HAI (Table 2, Fig. 3), at the same time-point as initial signs of diahrrea (96 HAI) and after the onset of hyperthermia (60 HAI) (Fig. 1). Clemente et al. (2016), studying buffalo calves infected with $S$. Typhimurium, verified progressive increase in fibrinogen concentration during infection, but also reported a slower increase compared to other APP such us ceruloplasmin and haptoglobin, reflecting its delay of a few days as acute phase reactant (Gruys et al., 2005).Thus, comparing the first $48 \mathrm{~h}$ response to infection, the fibrinogen reaction in the INF was weaker then ceruloplasmin, $\beta$-haptoglobin and $\alpha$-haptoglobin (Fig. 4).

Although initial increase in fibrinogen concentrations was slower compared to other APP in the INF, this protein showed important and significant peaks between 120 and $168 \mathrm{HAI}$, in the same way as $\beta$ haptoglobin, $\alpha$-haptoglobin and ceruloplasmin (Tables 1 and 2, Figs. 3 and 4), reinforcing the hypothesis that marked local inflammation in the gut caused by Salmonella can trigger APP production and, among other symptoms, also induce profuse diarrhea (Fagiolo et al., 2005). At peak points, between 120-168 HAI, fibrinogen increased up to $114 \%$, while ceruloplasmin, $\beta$-haptoglobin and $\alpha$-haptoglobin concentrations/ expression patterns increased up to $218 \%, 693 \%$ and $714 \%$, respectively, as showed by 1-DE and 2-DE results (Tables 1 and 2, Fig. 4). Therefore, haptoglobin, a major APP in ruminants that has previously been studied (Eckersall et al., 2001; Eckersall and Bell, 2010; Ceciliani et al., 2012), also works as a major APP during response to $S$. Dublin in buffalo calves, when compared to fibrinogen and ceruloplasmin, which have already been known as moderate APP in ruminants (Ceciliani et al., 2012). Indeed, ceruloplasmin and fibrinogen work as moderate APP during buffalo salmonellosis, being significantly increased during the infection and presenting very strong positive correlations with $\beta$ haptoglobin and $\alpha$-haptoglobin (Table 3). Therefore these APP can be useful tools when studying buffalo calves affected with $S$. Dublin.

One of the first lines of defense against bacterial infection is the withholding of nutrients to prevent bacterial outgrowth in a process termed nutritional immunity (Skaar, 2010) and the most significant form of nutritional immunity is the sequestration of nutrient iron (KehlFie and Skaar, 2009). Therefore, also part of the APR is the activation of a mechanism for restricting the availability of iron, in which the APP transferrin, among others, are involved (Schaible and Kaufmann, 2004). In the present study, iron serum concentrations significantly decreased by $33 \%$ and $37 \%$, in the INF, at 24 and $72 \mathrm{HAI}$, respectively, when compared to $0 \mathrm{~h}$, highlighting the fact that mechanisms for restricting iron availability is part of the APR (Table 2, Figs. 3 and 4). Horadagoda et al. (2002), studying experimentally Pasteurella multocida infected animals, showed a decrease in serum iron concentrations during the first $8 \mathrm{HAI}$, from $10.0 \mu \mathrm{mol} / \mathrm{L}(0 \mathrm{~h})$ to $2.8 \mu \mathrm{mol} / \mathrm{L}(8 \mathrm{~h}$, decrease of 257\%). Silva et al. (2010), studying newborn bovine calves infected with $S$. Dublin observed significant decrease in blood serum iron concentrations 48 HAI. Clemente et al. (2016), studying newborn buffalo calves infected with $S$. Typhimurium, also observed a significant decrease in iron concentrations $72 \mathrm{HAI}$, where concentrations were reduced in 58\% compared to before inoculation.

After decreasing between 24 and $72 \mathrm{~h}$, iron concentrations were restored between 96 and $168 \mathrm{HAI}$, but at $168 \mathrm{~h}$ still tended to be below concentrations measured before the inoculation (Table 2, Figs. 3 and 4), probably because the infection was still active, considering the fact that severe diarrhea was present and Salmonella was isolated in feces. This dynamics was also observed by Clemente et al. (2016), in buffalo calves infected with $S$. Typhimurium, where iron, after initial decrease, was restored but remained, $168 \mathrm{HAI}$, below baseline concentrations. The authors attributed this also to the fact that infection was still present.

Transferrin is an iron transporting protein involved in its intestinal absorption and cell internalization (Schaible and Kaufmann, 2004). In the present study, transferrin concentrations decreased between 72 and 120 HAI. Therefore, 72 HAI, transferrin concentrations were significantly lower than $24 \mathrm{HAI}$. Also, at the lowest concentration point, $120 \mathrm{HAI}$, transferrin was significantly lower than before inoculation. Clemente et al. (2016), studying buffalo calves infected with S. Typhimurium, also observed that transferrin worked as a negative APP, since concentrations progressively decreased until the end of the experiment.

Comparing the dynamics of iron and transferrin during the infection, it was observed that iron concentrations significantly decreased between 24 and $72 \mathrm{HAI}$, while transferrin significantly decreased between 72 and $120 \mathrm{HAI}$, shortly after iron. Iron began to be restored to basal concentrations before transferrin, 96 HAI against 144 HAI (Table 2, Fig. 3). Therefore, although decreased concentrations and recovery of basal concentrations of these variables occured in diferente time-points, changes in the concentrations of iron and transferrin in response to $S$. Dublin infection highlight the fact that mechanisms for restricting iron availability can be part of the APR. Normally transferrin works as a negative APP, that is, the host reduces the availability of this protein in the blood. This mechanism could be a response to bacterial infection since, in addition to acquiring iron from transferrin through siderophore-based mechanisms, some bacteria are capable of direct recognition of these host proteins, leading to iron removal and subsequent transport into the bacterial cytoplasm (Skaar, 2010).

In conclusion, the inoculation of $10^{8} \mathrm{CFU}$ was effective in inducing hyperthermia and diahrrea. Also, haptoglobin ( $\beta$-haptoglobin and $\alpha$ haptoglobin fractions), ceruloplasmin and fibrinogen worked as positive blood serum APP during the APR to $S$. Dublin infection and therefore are potential candidates to be used as biomarkers during $S$. Dublin infection in newborn buffalo calves. Also, blood serum concentrations of iron and transferrin decreased during the infection, highlighting the fact that mechanisms for restricting iron availability can be part of the APR triggered against $S$. Dublin infection in newborn buffalo calves.

\section{Acknowledgements}

This work was supported by São Paulo Research Foundation (FAPESP) [Grant process number: \#2008/50388-7, \#2009/05211-4, \#2009/05410-7, \#2009/12350-0, \#2012/10094-0, \#2013/26498-5]; Wellcome Trust [grant no. 097821/Z/11/Z] (Glasgow Polyomics). Suzanne McGill and Dr Christina Naula (Glasgow Polyomics) and Chris McComb (University of Glasgow) are thanked for their advice and assistance.

\section{References}

Albayrak, H., Kabu, M., 2016. Determining serum haptoglobin and cytokine 
concentrations in diarrheic calves. F.Ü. Sağ. Bil. Vet. Derg. 30, 113-117.

Ávila, L.G., Silva, D.G., Sato, R.A., Fagliari, J.J., 2011. Clinical evaluation of experimental Salmonella typhimurium-infection in calves. Arq. Bras. Med. Vet. Zootec. 63 1587-1590.

Bernardes, O., 2006. Os búfalos no Brasil. II Simpósio de Búfalo de Las Américas e II Simpósio Europa-América, Medellín, Proceedings... 3, 18-23 CD ROM.

Borriello, G., Lucibelli, M.G., Pesciaroli, M., Carullo, M.R., Graziani, C., Ammendola, S., Battistoni, A., Ercolini, D., Pasquali, P., Galiero, G., 2012. Diversity of Salmonella spp. serovars isolated from the intestines of water buffalo calves with gastroenteritis. BMC Vet. Res. 8, 201.

Ceciliani, F., Ceron, J.J., Eckersall, P.D., Sauerwein, H., 2012. Acute phase proteins in ruminants. J. Proteomics 75, 4207-4231.

Clemente, V., Santana, A.M., Silva, D.G., Silveira, C.R.A., Pizauro, L.J.L., Clemente, Z., Fagliari, J.J., 2016. Acute phase response in buffalo calves experimentally infected with Salmonella typhimurium. Pak. Vet. J. 36, 153-158.

Cray, C., Zaias, J., Altman, N.H., 2009. Acute phase response in animals: a review. Comp. Med. 59, 517-526.

Daneshvar, H., Wyllie, S., Phillips, S., Hagan, P., Burchmore, R., 2012. Comparative proteomics profiling of a gentamicin-attenuated Leishmania infantum cell line identifies key changes in parasite thiol-redox metabolism. Proteomics 75, $1463-1471$.

Deignan, T., Alwan, A., Kelly, J., McNair, J., Warren, T., O'Farrelly, C., 2000. Serum haptoglobin: an objective indicator of experimentally-induced Salmonella infections in calves. Res. Vet. Sci. 69, 153-158.

Eckersall, P.D., Bell, R., 2010. Acute phase proteins: biomarkers of infection and inflammation in veterinary medicine. Vet. J. 185, 23-27.

Eckersall, P.D., Duthie, S., Safi, S., Moffatt, D., Horadagoda, N.U., Doyle, S., Parton, R. Bennett, D., Fitzpatrick, J.L., 1999. An automated biochemical assay for haptoglobin: prevention of interference from albumin. Comp. Haematol. Int. 9, 117-124.

Eckersall, P.D., Young, F.J., McComb, C., Hogarth, C.J., Safi, S., Weber, A., McDonald, T., Nolan, A.M., Fitzpatrick, J.L., 2001. Acute phase proteins in serum and milk from dairy cows with clinical mastitis. Vet. Rec. 148, 35-41.

El-Deeb, W.M., Iacob, O.C., 2012. Serum acute phase proteins in control and Theileria annulata infected water buffaloes (Bubalus bubalis). Vet. Parasitol. 190, 12-18.

Fagiolo, A., Roncoroni, C., Lai, O., Borghese, A., 2005. Buffalo pathologies. In: Borghese, A. (Ed.), Buffalo Production and Research. FAO, Roma, pp. 249-296.

Fecteau, M.E., House, J.K., Kotarski, S.F., Tankersley, N.S., Ontiveros, M.M., Alcantar, C.R., Smith, B.P., 2003. Efficacy of ceftiofur for treatment of experimental salmonellosis in neonatal calves. Am. J. Vet. Res. 64, 918-925.

Food and Agriculture Organization of the United Nations (FAOSTAT), 2017. http://www. fao.org/faostat/en/\#data Accessed in 27/01/2017.

Gruys, E., Toussaint, M.J.M., Niewold, T.A., Koopmans, S.J., 2005. Acute phase reaction and acute phase proteins. J. Zhejiang Univ. Sci. 6B, 1045-1056.

Horadagoda, N.U., Hodgson, J.C., Moon, G.M., Wijewardana, T.G., Eckersall, P.D., 2002. Development of a clinical syndrome resembling haemorrhagic septicaemia in the buffalo following intravenous inoculation of Pasteurella multocida serotype B:2 endotoxin and the role of tumour necrosis factor- $\alpha$. Res. Vet. Sci. 72, 194-200.

Itoh, Y., Hirose, K., Miyake, M., Khan, A.Q., Hashimoto, Y., Ezaki, T., 1997. Amplification of $\mathrm{rfbE}$ e fliC genes by polimerase chain reaction for iden- tification and detection of Salmonella serovar Enteritidis, Dublin and Gallinarum-Pullorum. Microbiol. Immunol. 41, 791-794.

Kehl-Fie, T.E., Skaar, E.P., 2009. Nutritional immunity beyond iron: a role for manganese and zinc. Curr. Opin. Chem. Biol. 14, 218-224.

Khan, M.Z., Muhammad, G., Umar, A., Khan, S.A., 1997. A preliminary comparison of plasma fibrinogen concentrations, leukocyte numbers and erythrocyte sedimentation rate as non-specific indicators of inflammatory conditions in buffalo (Bubalis bubalis). Vet. Res. Commun. 21, 265-271.

Kumar, P., Sharma, A., Sindhu, N., Deora, A., 2014. Acute phase proteins as indicators of inflammation in streptococcal and staphylococcal mastitis in buffaloes. Haryana Vet. 53, 46-49.

Laemmli, U.K., 1970. Cleavage of structural proteins during the assembly of the head of bacteriophage T4. Nature (London) 227, 680-685.

Láu, H.D., 1999. Doenças em búfalos no Brasil: diagnóstico epidemiologia e controle. Embrapa, Brasilia 1999. 202 p.

Miles, A.A., Misra, S.S., 1938. The estimation of the bactericidal power of the blood. J. Hyg. (Lond.) 38, 732-749.

Millar, H.R., Simpson, J.G., Stalker, A.L., 1971. An evaluation of the heat precipitation method for plasma fibrinogen estimation. J. Clin. Pathol. 24, 827-830.

Ministry of Agriculture, Livestock and Food Supply (MAPA), 2017. http://www. agricultura.gov.br/arq_editor/file/Dados\%20de\%20rebanho\%20bovino\%20e \%20bubalino\%20do\%20Brasil\%202014.pdf. Accessed in 05/01/2017.

Radostits, O.M., Gay, C.C., Hinchcliff, K.W., 2007. Veternary Medicine - a Textbook of the Diseases of Cattle, Horses, Sheep, Pigs, and Goats, 10 Ed. Saunders, Philadelphia 673 762.

Santana, A.M., Thomas, F.C., Silva, D.G., McCulloch, E., Vidal, A.M.C., Burchmore, R.J.S. Fagliari, J.J., Eckersall, P.D., 2018. Reference 1D and 2D electrophoresis maps for potential disease related proteins in milk whey from lactating buffaloes and blood serum from buffalo calves (Water buffalo, Bubalus bubalis). Res. Vet. Sci. 118, 449-465.

Santos, R.L., Tsolis, R.M., Bäumler, A.J., Adams, L.G., 2002. Hematologic and serum biochemical changes in Salmonella ser Typhimurium-infected calves. Am. J. Vet. Res. $63,1145-1150$.

Schaible, U.E., Kaufmann, S.H.E., 2004. Iron and microbial infection. Nat. Rev. Microbiol. 2, 946-953.

Silva, D.G., Silva, P.R.L., Fagliari, J.J., Ávila, F.A., Alessi, A.C., Oliveira, R.G., 2008. Clinical evaluation of experimental Salmonella Dublin infection in calves. Arq. Bras. Med. Vet. Zootec. 60, 251-255.

Silva, D.G., Silva, P.R.L., Fagliari, J.J., 2010. Blood cell counts and serum biochemica profile, including blood gas levels, in Salmonella dublin-infected calves. Arq. Bras. Med. Vet. Zootec. 62, 251-257.

Silva, D.G., Silva, P.R.L., Silva, P.C., Fagliari, J.J., 2011. Serum protein concentrations, including acute phase proteins, in calves experimentally infected with Salmonella Dublin. Pesqui. Vet. Bras. 31, 551-554.

Skaar, E.P., 2010. The battle for iron between bacterial pathogens and their vertebrate hosts. PLoS Pathog. 6, e1000949. https://doi.org/10.1371/journal.ppat.1000949.

Tajik, J., Nazifi, S., Heidari, M., Babazadeh, M., 2012. Serum concentrations of haptoglobin and serum amyloid A in water buffaloes (Bubalus bubalis) with abomasal ulcer. Vet. Res. Forum 3, 209-212.

Tremblay, R.R., 1990. Intravenous fluid therapy in calves. Vet. Clin. North Am. Food Anim. Pract. 6, 77-101.

Villarreal-Ramos, B., Manser, J.M., Collins, R.A., Chance, V., Eckersall, P.D., Jones, P.W., Dougan, G., 2000. Susceptibility of calves to challenge with Salmonella typhimurium 4/74 and derivatives harbouring mutations in htrA or purE. Microbiology 146, $2775-2783$. 